\title{
Oxygenated organic functional groups and their sources in single and submicron organic particles in MILAGRO 2006 campaign
}

\author{
S. Liu ${ }^{1}$, S. Takahama ${ }^{1}$, L. M. Russell ${ }^{1}$, S. Gilardoni ${ }^{1,2}$, and D. Baumgardner ${ }^{3}$ \\ ${ }^{1}$ Scripps Institution of Oceanography, Univ. of California, San Diego, La Jolla, California, USA \\ ${ }^{2}$ Joint Research Centre, European Commission, Ispra, Italy \\ ${ }^{3}$ Centro de Ciencias de la Atmósfera, Univ. Nacional Autónoma de México, México City, México
}

Received: 15 December 2008 - Published in Atmos. Chem. Phys. Discuss.: 23 February 2009

Revised: 9 July 2009 - Accepted: 26 August 2009 - Published: 21 September 2009

\begin{abstract}
Fourier Transform Infrared (FTIR) and X-ray Fluorescence (XRF) were used to measure organic functional groups and elements of submicron particles collected during MILAGRO in March 2006 on three platforms: the Mexico City urban area (SIMAT), the high altitude site at $4010 \mathrm{~m}$ (Altzomoni), and the NCAR C130 aircraft. Scanning Transmission X-ray Microscopy (STXM) and Near-Edge X-ray Absorption Fine Structure (NEXAFS) were applied to single particle organic functional group abundance analysis of particles simultaneously collected at SIMAT and C130. Correlations of elemental concentrations showed different groups of source-related elements at SIMAT, Altzomoni, and C130, suggesting different processes affecting the air masses sampled at the three platforms. Cluster analysis resulted in seven distinct clusters of FTIR spectra, with the last three clusters consisting of spectra collected almost exclusively on the C130 platform, reflecting the variety of sources contributing to C130 samples. Positive Matrix Factorization (PMF) of STXM-NEXAFS spectra identified three main factors representing soot, secondary, and biomass burning type spectra. PMF of FTIR spectra resulted in two fossil fuel combustion factors and one biomass burning factor, the former representative of source regions to the northeast and southwest of SIMAT. Alkane, carboxylic acid, amine, and alcohol functional groups were mainly associated with combustion related sources, while non-acid carbonyl groups were likely from biomass burning events. The majority of $\mathrm{OM}$ and $\mathrm{O} / \mathrm{C}$ was attributed to combustion sources, although no distinction between direct emissions and atmospherically processed $\mathrm{OM}$ could be identified.
\end{abstract}

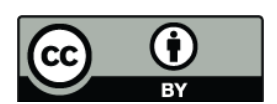

Correspondence to: L. M. Russell (lmrussell@ucsd.edu)

\section{Introduction}

Atmospheric aerosols have been causing increased concerns during the last few decades since they reduce air quality (Eidels-Dubovoi, 2002), threaten human health (Dockery et al., 1993), and affect climate (Liepert et al., 2004). The effects of organic aerosols remain largely unknown because of their complex composition, especially in urban areas. The Mexico City Metropolitan Area (MCMA) is the second largest megacity in the world. Although its pollution problem has been studied for more than 40 years (Raga et al., 2001), there are only a limited number of organic aerosol measurements (Salcedo et al., 2006; DeCarlo et al., 2008; Aiken et al., 2008). The main sources of MCMA aerosols include biomass burning (Johnson et al., 2006; Salcedo et al., 2006; Molina et al., 2007), motor vehicle emissions, oil burning, and crustal components (Querol et al., 2008; Stone et al., 2008).

The MILAGRO (Megacity Initiative: Local and Global Research Observations) campaign is the largest intensive measurement to date in the MCMA to quantify properties of atmospheric aerosols. This study builds on the measurements presented by Gilardoni et al. (2009) to identify overall statistical trends that span the organic aerosol properties across the MCMA basin. Site-by-site correlations, clusters of organic types, and underlying source-related factors are combined in this work to identify the contributions to organic mass from the major source types in the MCMA. In this work we also establish that the same organic functional group signatures and source types found in bulk submicron samples are evident in external mixtures of internally mixed single particles.

Gilardoni et al. (2009) have shown that the organic mass (OM) measurements from FTIR were well correlated with

Published by Copernicus Publications on behalf of the European Geosciences Union. 
simultaneous Aerosol Mass Spectrometry (AMS) measurements during this campaign. Alkane functional groups dominated the OM. The average $\mathrm{OM} / \mathrm{OC}$ and carboxylic acid $\mathrm{COOH}$ to aliphatic saturated $\mathrm{C}-\mathrm{C}-\mathrm{H}$ ratios were higher at Altzomoni than at SIMAT, as a consequence of a larger contribution of oxidized functional groups. The $\mathrm{OM}$ was found to correlate with non-soil $\mathrm{K}$, indicating biomass burning being a source of OM in the MCMA.

In this paper, we will extend their work using chemometric techniques and specific statistical tests to identify additional and significant trends in the measurements, in particular for normalized organic functional group composition and fraction of oxidized organic carbon. Correlations of each pair of elements and organic functional groups were investigated. The co-varying of organic functional groups with elemental markers provides an indication of the fraction of organic compound associated with specific metal source signatures. Ward clustering (Ward, 1963) was applied to FTIR spectra to identify the similarities and differences across the three platforms. In addition, PMF was applied to STXMNEXAFS and FTIR spectra independently to identify the contributions of some general classes of sources to the organic particles. PMF factor time series were correlated to time series of source-specific elements to link factors to the sources that emitted them, in either the gas or particle phase. This work illustrates important differences in the characteristics of the organic mixtures from biomass burning and combustion sources for SIMAT, Altzomoni, and C130 flight measurements, and the analysis quantifies the approximate contribution of each source type to OM in the MCMA and surrounding areas.

\section{Methods}

Submicron particles were collected on Teflon filters in March 2006, during the MIRAGE (Megacity Impacts on Regional and Global Environments)/MILAGRO field campaign. The SIMAT site is located at the Mexico City Atmospheric Monitoring System building $\left(19^{\circ} 24^{\prime} 12^{\prime \prime} \mathrm{N}, 99^{\circ} 10^{\prime} 34^{\prime \prime} \mathrm{W}\right)$, and the Altzomoni site is located about $60 \mathrm{~km}$ southeast of Mexico City, in the Pass of Cortez between the volcanoes of Popocatépetl and Iztaccíhuatl $\left(19^{\circ} 7^{\prime} \mathrm{N}, 98^{\circ} 38^{\prime} \mathrm{W}\right.$; Baumgardner et al., 2009). At SIMAT and Altzomoni, two 12-h samples or three 8-h samples were collected along with one 24-h sample. Samples were collected for $20 \mathrm{~min}$ to $1 \mathrm{~h}$ on board NCAR C130 at constant altitudes. A field blank was simultaneously collected with each sample. Samples were stored below $0^{\circ} \mathrm{C}$ after collection before FTIR analysis. The FTIR spectra were quantified as mass concentrations of organic functional groups using an automated algorithm (Russell et al., 2009), including additional calibrations of primary amine functional groups (Appendix A) in addition to standard compound calibrations presented in previous work (Maria et al., 2002, 2003, 2004; Maria and Russell, 2005; Gi- lardoni et al., 2007). The field blank spectra were baselined using the same algorithm.

Elements heavier than $\mathrm{Na}$ (including $\mathrm{Na}$ ) were analyzed by Chester Laboratories on the same filters used for the FTIR analysis (Maria et al., 2003). Elemental concentrations reported were above detection limit for more than $70 \%$ of the ambient samples collected. The elements $\mathrm{Mg}, \mathrm{P}, \mathrm{Co}, \mathrm{Ga}, \mathrm{Ge}$, As, Rb, Sr, Y, Zr, Mo, Pd, Ag, Cd, In, Sb, La, and Hg were always below detection limits. A data matrix was constructed including organic functional group concentrations and elemental concentrations for each sample filter. Correlations of each pair of components were calculated to provide the covariance of these aerosol components and to investigate possible sources.

Normalized FTIR spectra of three platforms were grouped into clusters using the Agglomerative Hierarchical Clustering technique with the Ward algorithm. In this algorithm, each spectrum is initially considered as a separate category, a dendrogram is built from the spectra by progressively merging them and minimizing the sum-of-square errors for the spectra being merged (ultimately resulting in all spectra collapsing into one single category). The dendrogram can be grouped into clusters by choosing a level of branching (similarity) that results in a meaningful number of categories (Kaufman et al., 1990). In this work, seven clusters were selected.

Positive matrix factorization (PMF) was applied to all 263 mass-weighted baselined FTIR spectra of three platforms (Paatero et al., 1994; Russell et al., 2009). PMF can be used to infer unknown source profiles and source contributions from ambient measurements (Lee et al., 1999; Ramadan et al., 2000). Baselining error (which was calculated from the variability of the baselined field blank spectra) was used to estimate the scaling factor as a function of wavelength (Appendices in Russell et al., 2009). The robust mode of PMF was used, and the outliers were downweighted during the fitting procedure. Fixed Size Moving Window - Evolving Factor Analysis (FSMW-EFA) was applied to the spectra from all three sites for the determination of the number of factors. FSMW-EFA performs Singular Value Decomposition (SVD) analysis on a subset of spectra contained in a "window" of a fixed size, which is moved along the spectra (Keller et al., 1992). The results of the analysis on all "windows" were plotted together to show the percentage of data recovery at each wavenumber using different numbers of factors. The rotation parameter FPEAK was set to $-0.2,0,0.2$, and 0.4 since FPEAK $\leq-0.4$ and FPEAK $\geq 0.6$ resulted in physically unrealistic spectra (e.g. non-Gaussian spectra). The effects of rotation were small, likely because the non-negativity constraint was set for more than 1500 wavenumbers. FPEAK=0 was used to represent the solutions. The output sample contribution factor was normalized by volume and correlated to metal concentrations to identify sources most likely associated with each factor. 
Table 1. Mean and standard deviation of OM, organic functional group concentrations, O/C and OM/OC ratios, and elemental concentrations for SIMAT, Altzomoni, and C130 platforms measured by FTIR and XRF.

\begin{tabular}{|c|c|c|c|c|}
\hline & & SIMAT & Altzomoni & $\mathrm{C} 130$ \\
\hline & $\begin{array}{l}\text { FTIR OM } \mu \mathrm{g} \mathrm{m}^{-3} \\
\text { FTIR OM/OC } \\
\text { FTIR O/C }\end{array}$ & $\begin{array}{l}9.9 \pm 4.4 \\
1.8 \pm 0.1 \\
0.4 \pm 0.1\end{array}$ & $\begin{array}{l}6.6 \pm 3.9 \\
2.0 \pm 0.3 \\
0.5 \pm 0.1\end{array}$ & $\begin{array}{l}5.3 \pm 4.2 \\
1.5 \pm 0.2 \\
0.2 \pm 0.2\end{array}$ \\
\hline $\begin{array}{l}\text { FTIR Organic Functional Groups } \\
\left(\mu \mathrm{g} \mathrm{m}^{-3}\right)\end{array}$ & $\begin{array}{l}\text { Alcohol } \\
\text { Alkane } \\
\text { Non-Acid Carbonyl } \\
\text { Amine } \\
\text { Carboxylic Acid }\end{array}$ & $\begin{array}{l}1.5 \pm 1.0(14 \%) \\
4.6 \pm 2.0(47 \%) \\
0.0 \pm 0.3(0 \%) \\
0.8 \pm 0.3(9 \%) \\
3.0 \pm 1.4(30 \%)\end{array}$ & $\begin{array}{l}1.1 \pm 1.2(19 \%) \\
2.7 \pm 1.5(41 \%) \\
0.1 \pm 0.3(1 \%) \\
0.7 \pm 0.5(11 \%) \\
2.0 \pm 1.1(28 \%)\end{array}$ & $\begin{array}{l}1.1 \pm 1.3(19 \%) \\
3.4 \pm 2.0(73 \%) \\
0.1 \pm 0.6(0 \%) \\
0.1 \pm 0.3(2 \%) \\
0.5 \pm 1.4(5 \%)\end{array}$ \\
\hline $\begin{array}{l}\text { XRF Elements } \\
\left(\mathrm{ng} \mathrm{m}^{-3}\right)\end{array}$ & $\begin{array}{l}\mathrm{Na} \\
\mathrm{Al} \\
\mathrm{Si} \\
\mathrm{S} \\
\mathrm{Cl} \\
\mathrm{K} \\
\mathrm{Ca} \\
\mathrm{Ti} \\
\mathrm{V} \\
\mathrm{Cr} \\
\mathrm{Mn} \\
\mathrm{Fe} \\
\mathrm{Ni} \\
\mathrm{C} \\
\mathrm{Zn} \\
\mathrm{Se} \\
\mathrm{Br} \\
\mathrm{Sn}\end{array}$ & $\begin{array}{l}91.3 \pm 93.2 \\
51.2 \pm 63.5 \\
133 \pm 126 \\
955 \pm 517 \\
40.9 \pm 40.1 \\
168 \pm 86.5 \\
107 \pm 115 \\
4.5 \pm 4.3 \\
7.8 \pm 14.0 \\
0.9 \pm 1.2 \\
4.3 \pm 4.4 \\
92.9 \pm 73.4 \\
1.6 \pm 2.7 \\
9.6 \pm 10.9 \\
36.4 \pm 29.3 \\
3.3 \pm 4.6 \\
6.3 \pm 7.6 \\
6.6 \pm 7.3\end{array}$ & $\begin{array}{l}50.8 \pm 86.3 \\
134 \pm 249 \\
706 \pm 462 \\
160 \pm 105 \\
83.6 \pm 212 \\
3.2 \pm 4.6 \\
2.3 \pm 2.6 \\
0.9 \pm 1.7\end{array}$ & $\begin{array}{l}125 \pm 112 \\
135 \pm 108 \\
476 \pm 476 \\
96.7 \pm 60.3 \\
25.4 \pm 18.5 \\
9.5 \pm 9.8 \\
25.9 \pm 23.4 \\
15.1 \pm 11.6 \\
68.5 \pm 69.4\end{array}$ \\
\hline
\end{tabular}

Potential Source Contribution Function (PSCF; Pekney et al., 2006) analysis was used to determine the most probable potential source regions to each PMF factor. PSCF calculates the probability that a source is located at a particular geographical region. Eight-hour long back trajectories ending at the SIMAT and Altzomoni coordinates were computed each hour at $200 \mathrm{~m}$ above ground level for the entire campaign using the Hybrid Single-Particle Lagrangian Integrated Trajectory (HYSPLIT) model (Escudero et al., 2006). These trajectories were grouped into periods in which PMF source contributions were either high or low. Periods in which the source contribution for each factor was higher than its 75 th percentile value were classified as high periods, and the rest of the periods were classified as low. The trajectories were interpolated into 15-min intervals and superposed on a 4 (latitude) $\times 4$ (longitude) degree domain centered around the city and gridded into a total of 250000 cells. Frequencies for high and low periods were normalized by total counts for each grid cell for the PSCF analysis (Pekney et al., 2006). To reduce the uncertainties of large ratios in cells with low trajectory endpoints, a cumulative distribution function of trajectory endpoints in grid cells was used to set a threshold of $40 \%$ so that the cells with less than 10 trajectory endpoints were not considered in the PSCF calculation.
Particles were also collected on silicon nitride windows, and single particle K-edge X-ray absorption spectra were acquired using a combination of Scanning Transmission X-ray Microscopy (STXM) and Near-Edge X-ray Absorption Fine Structure (NEXAFS) spectroscopy at the Lawrence Berkeley National Laboratory Advanced Light Source on beam line 5.3.2 (Russell et al., 2002; Maria et al., 2004). PMF was applied to the total 270 STXM-NEXAFS spectra of SIMAT and $\mathrm{C} 130$ measurements. The rotation parameter and the number of factors were explored similarly to PMF of FTIR spectra. FPEAK was set to $-0.2,0,0.2$, and 0.4 for 2 to 8 factors. Two to eight factors were found to reproduce $85-99 \%$ of the measured abundances. The 4-factor solution with FPEAK set to 0 produced the most representative results by comparing factor spectra with standard reference spectra.

\section{Results}

The average OM concentrations at STP were $9.9 \mu \mathrm{g} \mathrm{m}^{-3}$ at SIMAT, $6.6 \mu \mathrm{g} \mathrm{m}^{-3}$ at Altzomoni, and $5.3 \mu \mathrm{g} \mathrm{m}^{-3}$ on the C130 (Gilardoni et al., 2009). Alkane functional groups dominated the total OM, with the mass fractions $47 \%, 41 \%$, and $73 \%$ for SIMAT, Altzomoni, and C130 measurements, respectively. Carboxylic acid functional groups contributed 
$30 \%$ and $28 \%$ to OM at SIMAT and Altzomoni, with a lower fraction of $5 \%$ on average for the $\mathrm{C} 130$ flights. Alcohol functional groups accounted for $14 \%$ of OM at SIMAT, with larger fractions of $19 \%$ both at Altzomoni and on the C130. The mass fractions of primary amine functional groups were $9 \%$ at SIMAT, $11 \%$ at Altzomoni, and 2\% on the $\mathrm{C} 130$ (Table 1). Of the $\mathrm{C} 130$ samples, $87 \%$ of amine functional group masses and $73 \%$ of carboxylic acid functional group masses were below detection limit, and typically could have accounted for up to $1 \%$ and $15 \%$ of OM, respectively. FTIR spectra were analyzed for evidence consistent with organosulfate functional groups, but no samples had detectable absorbance at $876 \mathrm{~cm}^{-1}$. Alkene and aromatic functional group masses were below detection limit in all samples of the three platforms, accounting for less than $1 \%$ of the average OM. All of the normalized and fractional quantities in the following discussion omit these two functional groups.

The Oxygen-to-Carbon ratio $(\mathrm{O} / \mathrm{C})$ can be estimated from FTIR measurements (Russell et al., 2009). The average FTIR $\mathrm{O} / \mathrm{C}$ was 0.4 for SIMAT, and this value is comparable to the AMS O/C $=0.41$ at the nearby $\mathrm{T} 0$ sampling site $(9 \mathrm{~km}$ north of SIMAT sampling site) from AMS-based estimates (Aiken et al., 2008). The FTIR O/C was compared with the O/C calculated from quadrupole AMS measurements using the reported ambient relationship for $\mathrm{m} / \mathrm{z} 44$ (Aiken et al., 2008; Shilling et al., 2009) for Altzomoni and C130 platforms. At Altzomoni, the FTIR O/C was consistently lower than the AMS O/C, but the differences were within the uncertainties of both FTIR and AMS. On the C130, the FTIR and AMSbased O/C compared well for the samples with carboxylic acid functional groups above detection limit. These comparisons are consistent with the previous study (Russell et al., 2009), showing that the O/C estimates from FTIR and AMS are within the uncertainties associated with inlet transmission. The standard deviations of FTIR O/C were 0.07 , 0.12, and 0.18 for SIMAT, Altzomoni, and C130 measurements, respectively. The larger $\mathrm{O} / \mathrm{C}$ variation during the NCAR C130 flights indicates that the larger altitude and geographic range of these measurements showed greater variability in organic composition than either of the two ground sites.

\subsection{Correlations in concentrations}

The SIMAT measurements showed correlations of elemental markers from three groups: dust elemental markers (Al, $\mathrm{Si}, \mathrm{Ca}, \mathrm{Ti}, \mathrm{Fe}$ ) correlated with each other, with correlation coefficients $(r)$ ranging from 0.5 to $0.9 ; \mathrm{S}$ and Se were correlated with $r$ of 0.55 , indicating coal combustion source types (Qureshi et al., 2006); V and Ni are indicators of oil combustion (Qureshi et al., 2006), they were correlated with $r$ of 0.87. Concentrations of alcohol, alkane, amine, and carboxylic acid functional groups correlated with each other as well as $\mathrm{S}$, suggesting their common combustion sources. Alkane and carboxylic acid group mass fractions correlated

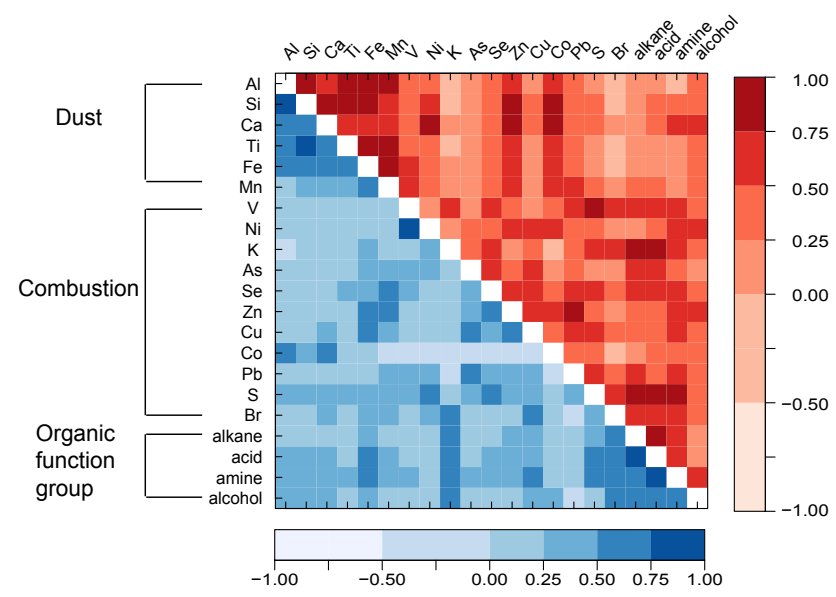

Fig. 1. Correlations of organic functional group and elemental concentrations for SIMAT (blue) and Altzomoni (red) samples. Color bars indicate correlation coefficients.

with each other, but they anti-correlated with alcohol group mass fraction, indicating that the alcohol group was dominated by different source types or processes from alkane and carboxylic acid groups.

At Altzomoni, dust elemental markers (Al, $\mathrm{Si}, \mathrm{Ca}, \mathrm{Ti}$, and $\mathrm{Fe}$ ) were correlated with each other with $r$ ranging from 0.6 to 1.0 , and combustion elemental markers $(\mathrm{V}, \mathrm{S}, \mathrm{K}, \mathrm{Br}, \mathrm{Pb}$, and $\mathrm{Se}$ ) were correlated with each other with $r$ ranging from 0.5 to 0.7 (Fig. 1). The high correlations of the dust elemental concentrations may be caused by the single-lane local road, which is located $5 \mathrm{~km}$ southeast from Altzomoni site (Baumgardner et al., 2009). Compared to SIMAT and other urban sites (Russell et al., 2009), the combustion-generated components did not fall into clear fuel-specific combustion categories, consistent with higher contributions of more processed or mixed-source organic mass at Altzomoni. This result is also consistent with a higher $\mathrm{O} / \mathrm{C}$ and $\mathrm{OM} / \mathrm{OC}$ at Altzomoni than at SIMAT. Similar to SIMAT, concentrations of alkane, amine, and carboxylic acid functional groups at Altzomoni correlated with each other as well as S, likely from industrial or diesel vehicular emissions. Alkane and carboxylic acid group mass fractions were correlated with each other but were anti-correlated with alcohol group mass fractions.

Dust elemental markers ( $\mathrm{Si}, \mathrm{Ca}$, and $\mathrm{Fe}$ ) were correlated with each other, with $r$ ranging from 0.5 to 0.6 for the C130 measurements; $\mathrm{Ca}$ also correlated with combustion and industrial markers ( $\mathrm{S}, \mathrm{K}$, and $\mathrm{V}$ ) with $r$ of $0.4,0.5$ and 0.6 , respectively, indicating particles from mixed source types. The correlations between organic functional groups and elements were weak, indicating that the particles were mixed or processed during atmospheric transport, leaving no clear source signature. Concentrations of alcohol and alkane functional groups correlate with each other, but the mass fractions of alcohol and alkane functional groups were anti-correlated. 


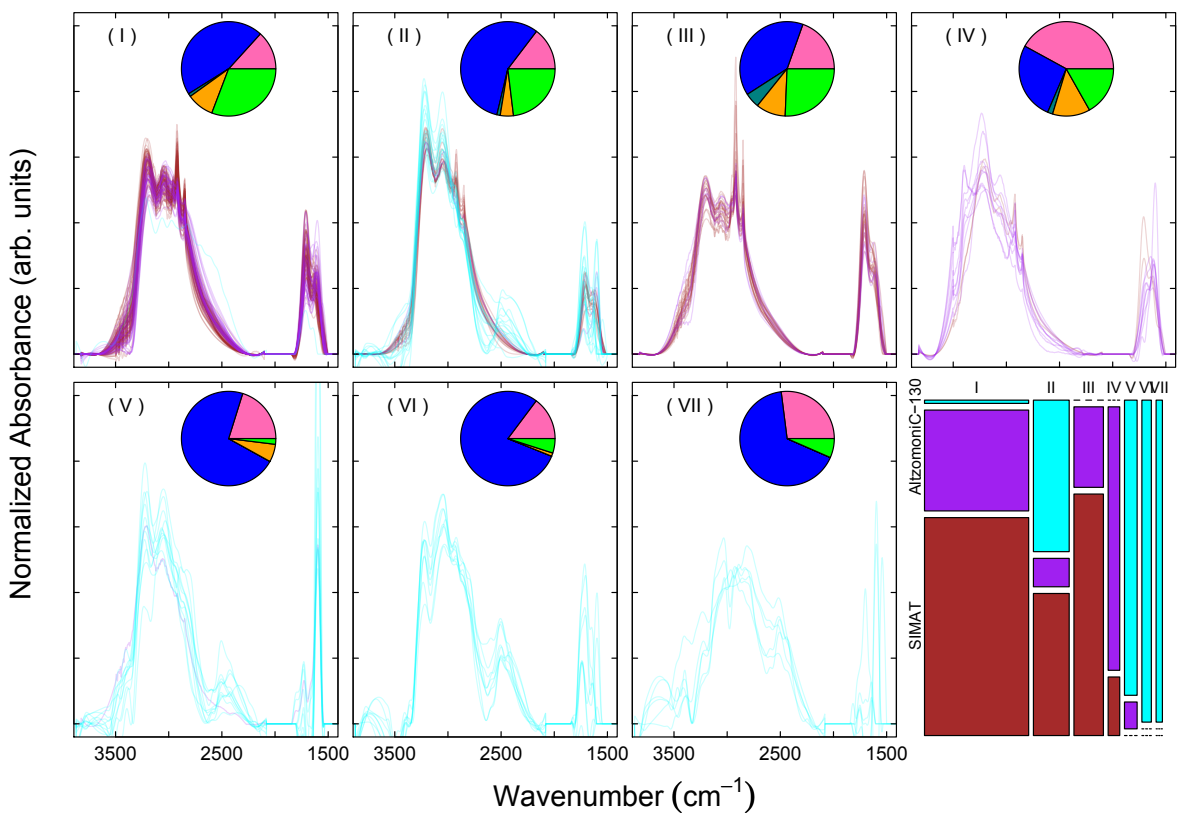

Fig. 2. FTIR spectra from cluster categories I-VII (Panels I-VII). The last panel shows the cluster-platform comparison: the width of the bar is proportional to the number of spectra in each cluster and the height of the bar represents the fraction of spectra from each platform. Colors indicate SIMAT (brown), Altzomoni (green), and C130 (blue). The pie chart in each cluster panel shows the average organic functional group fractions of the cluster.

\subsection{Cluster analysis of FTIR spectra}

Cluster analysis was used to identify similarities among the measured normalized FTIR spectra. The Ward-type cluster analysis method was used and two to ten branches were tested. Spectra from the C130 measurements were separated from the Altzomoni and SIMAT spectra at the first branch; Altzomoni spectra started to be separated when five or more branches were used. Seven clusters were used to best represent different types of FTIR spectra associated with different organic functional group compositions (Fig. 2). Using more than seven clusters resulted in small clusters consisting of only two C130 spectra, which were not statistically significant.

Clusters I, II, and III were the dominant clusters, as they contained $65 \%$ of the spectra. Seventy-percent of the spectra from clusters I and III were from SIMAT and the other 30\% were from Altzomoni, with the difference between these two clusters being the presence of sharper peaks in the alkane functional group region of cluster III spectra. Samples from cluster III also had the lowest O/C among clusters I-IV. Forty-percent of the spectra in cluster II were from SIMAT and $45 \%$ from $\mathrm{C} 130$ measurements. The $\mathrm{C} 130$ samples in this cluster were collected at lower altitudes and closer to the Mexico City basin than the samples in the other clusters, indicating these samples were influenced by the city outflow. Samples from this cluster had the largest alkane functional group fraction among clusters I-IV. The similarities among spectra from different platforms suggest that many of the sources were associated with region-wide pollution that was transported in air masses sampled by all three platforms, which is consistent with the findings of Baumgardner et al. (2009). $85 \%$ of the spectra in cluster IV were from Altzomoni and $15 \%$ from SIMAT. The average O/C of the samples in cluster IV was significantly higher (at a $95 \%$ confidence level) than $\mathrm{O} / \mathrm{C}$ of the samples in the other clusters, and samples from this cluster had the largest alcohol functional group fraction among all clusters. Clusters V, VI, and VII consisted almost exclusively of C130 spectra, with only $5 \%$ of the spectra from Altzomoni in cluster V. The three distinct branches of clusters of $\mathrm{C} 130$ measurements separated from the ground site measurements indicates the wide variety of different sources and air masses sampled by the C130.

\subsection{Positive matrix factorization of FTIR spectra}

PMF was applied to the FTIR spectra of the three platforms ("combined PMF") and spectra from each site separately ("separate PMF") using three to six factors. By investigating factor chemical compositions, time series, and their possible source regions, similar factors were identified from both "combined PMF" and "separate PMF", indicating similar sources and regional pollution in the MCMA. The five- and six-factor solutions resulted in correlated factors with similar compositions and source regions, indicating some factors split into smaller but indistinguishable components because too many factors were used given the size of the data 
Table 2. Correlations of PMF factors to elements with $r>0.5$ (bold) and $0.25<r<0.5$, average organic mass concentrations $\mu \mathrm{g} \mathrm{m}^{-3}$, and pie charts of organic functional group mass contributions by sampling platforms. Colors indicate alkane (blue), alcohol (pink), carboxylic acid (green), amine (orange), and non-acid carbonyl (teal) functional groups.

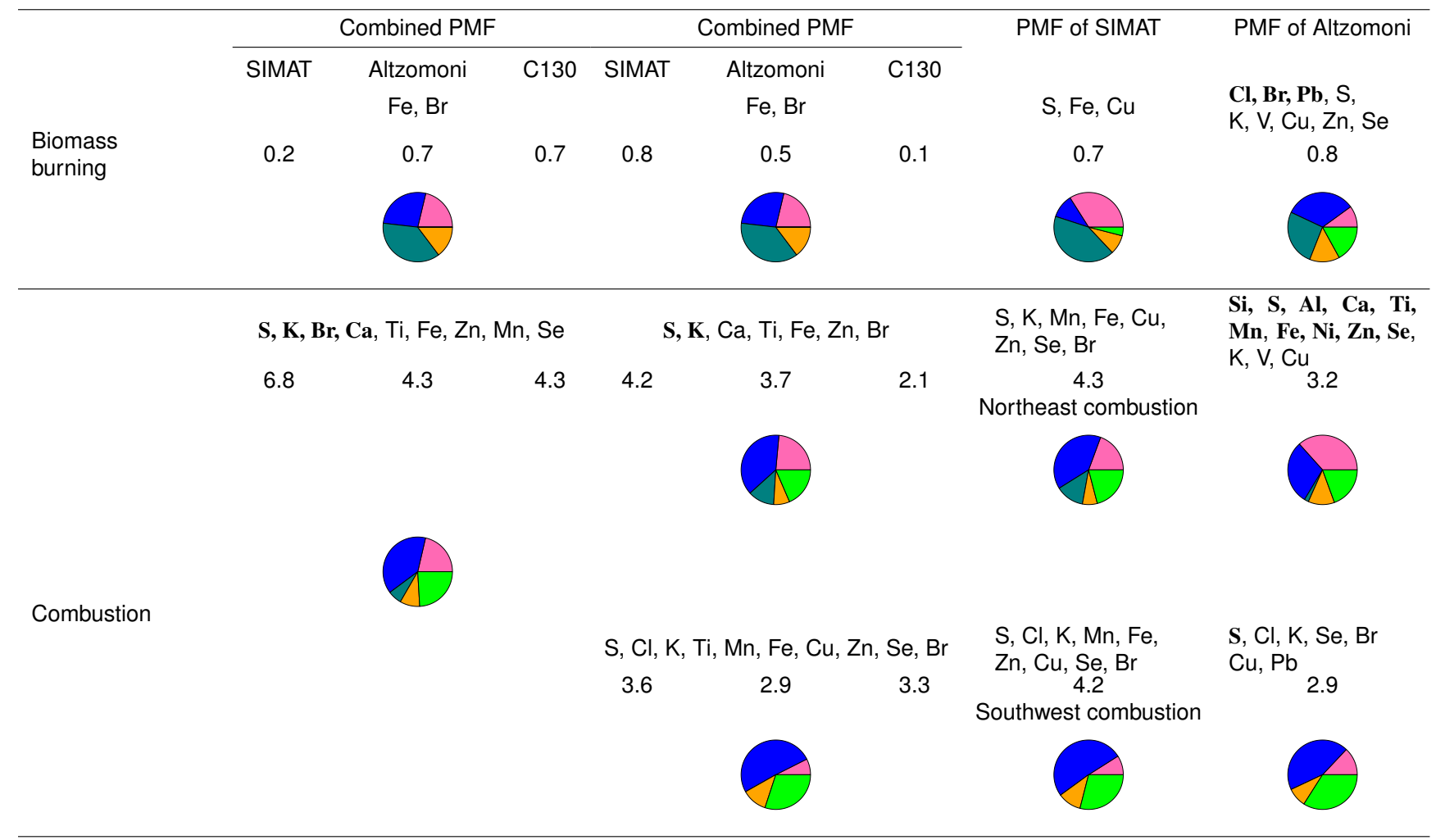

set. A distinct factor with significant mass was missing when three factors were used, causing the OM reconstructed from the factors to under-represent the measured $\mathrm{OM}$. The fourfactor solution was selected because four factors were found to reproduce $98 \%$ of the measured mass and to generate factors that represented sufficient organic mass for interpretation. Both the "combined PMF" and the "separate PMF" (calculated separately for the SIMAT and Altzomoni measurements) solutions are discussed below to show the consistency and quantitative variability of the PMF solutions, with the time series of OM concentrations for PMF factors shown in Fig. 3. The apportionment of OM concentrations and $\mathrm{OC}$-weighted $\mathrm{O} / \mathrm{C}$ to the factors are shown in Fig. 4. The functional group concentrations of these factors are summarized in Table 2 for SIMAT and Altzmoni measurements. The OM concentration of each factor was correlated with the corresponding elemental concentrations to show the contributions of different source types to organic functional groups. For each factor, correlations to elements with $r>0.5$ and $0.25<r<0.5$ are listed in Table 2 .

The first factor was persistent in all PMF runs and was identified as a biomass burning factor, since the $\mathrm{OM}$ of this factor increased significantly during the fire period (12-14 March 2006) at $99 \%$ confidence level, while the other fac- tors did not show strong correspondence with the fire period. The fire period was identified by Aiken et al. (2009) by measuring biomass burning tracers including potassium, levoglucosan, and acetonitrile at the T0 site. This result is consistent with the effects of biomass burning events on the organic mass concentrations of Mexico City described elsewhere (Moffet et al., 2008b; Gilardoni et al., 2009). PSCF of this factor showed that the potential source of this factor was located south of the SIMAT and Altzomoni sites (Fig. 5a, d) in the mixed forest region (Yokelson et al., 2007). This source region also matches well with the possible source region of aged biomass burning particles described by Moffet et al. (2008b) from single particle analysis. Non-acid carbonyl functional groups dominated this factor, accounting for $26-47 \%$ of the OM. The OM contribution of this factor at SIMAT was comparable to the OM contribution of this factor at Altzomoni, indicating that biomass burning had a regional influence during the MILAGRO campaign.

The three remaining factors were identified as fossil fuel combustion type factors because they were associated with more than one elemental marker of fossil fuel combustion. Similar metal combustion tracers were associated with these factors. All three remaining factors had weak correlations with $\mathrm{K}$ and $\mathrm{Br}$; and two also had weak or mild correlations 

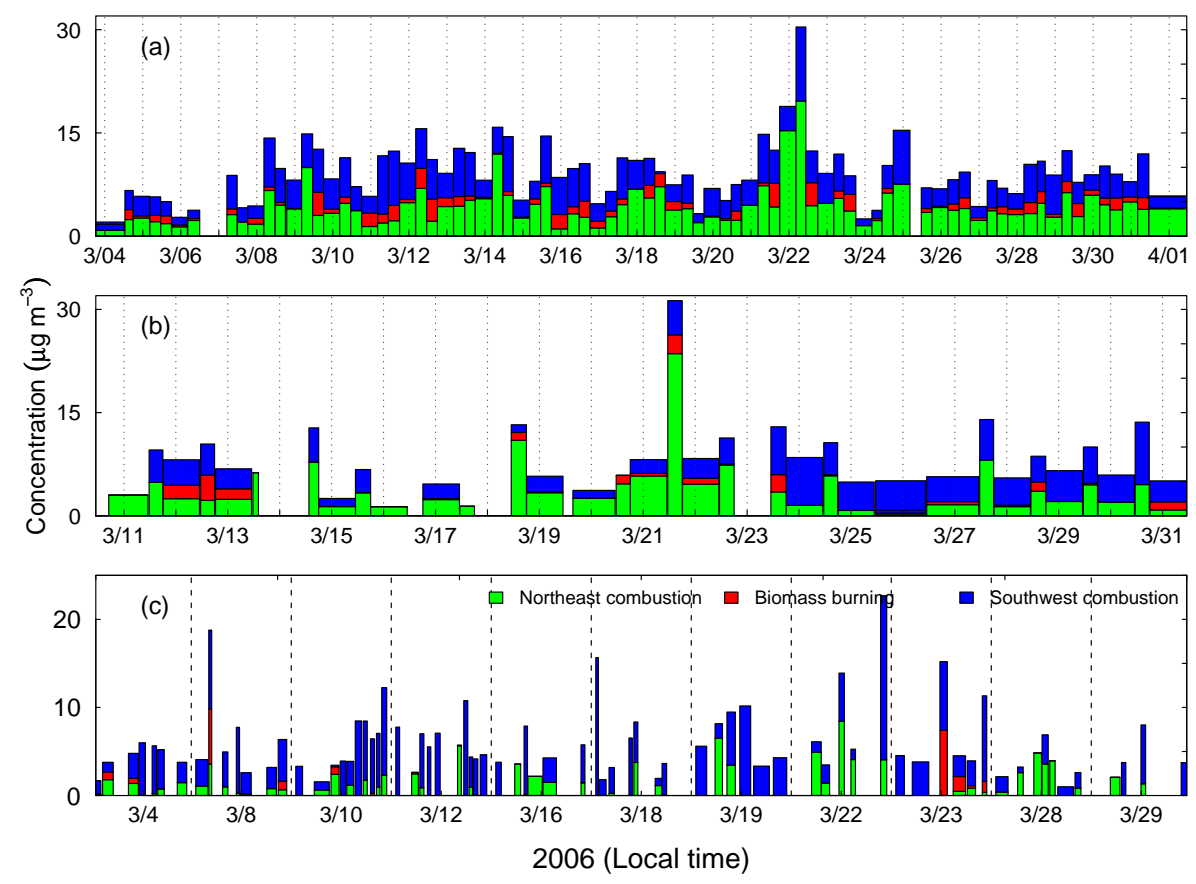

Fig. 3. OM concentrations of northeast combustion (green), biomass burning (red), and southwest combustion (blue) factors for SIMAT (a), Altzomoni (b), and C130 (c) samples.

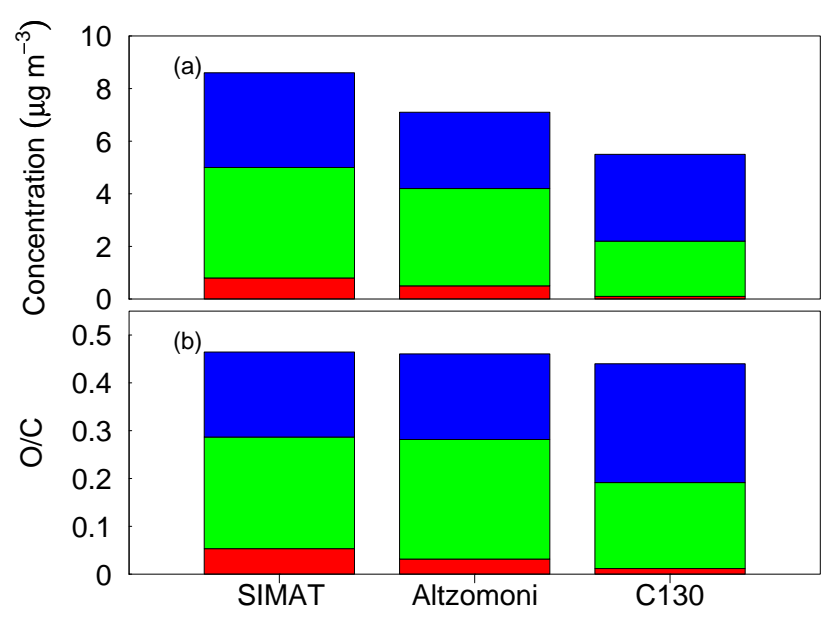

Fig. 4. Average contributions of (a) OM concentrations and (b) $\mathrm{O} / \mathrm{C}$ of northeast combustion (green), biomass burning (red), and southwest combustion (blue) factors for SIMAT, Altzomoni, and C130 platforms.

with $\mathrm{S}, \mathrm{Se}, \mathrm{Cu}, \mathrm{Zn}, \mathrm{Fe}$, and $\mathrm{Mn}$. These elements can be attributed to various combustion processes, for example, $\mathrm{S}$ could be emitted from industrial or motor vehicular combustions using fossil fuels (Flore et al., 1999). The other sources of these elements could also include oil burning, coal burning, and solid waste incineration (Sharma et al., 2005; Li et al., 2004; Balasubramanian et al., 2004; Finlayson-Pitts et al., 2000). The combustion sources around Mexico City include incineration (Moffet et al., 2008a), oil combustion (Flore et al., 1999; Moffet et al., 2008b), motor vehicle emissions (Vega et al., 1997; Chow et al., 2002; Querol et al., 2008; Stone et al., 2008), and local charcoal burning (CICA, 1999), which can produce the elements associated with these three factors. While some studies show diurnal trends and weekday or weekend variations of OC (Stone et al., 2008), none of these factors were found to have these patterns. As a result, there were insufficient constraints to separate these factors by specific source types. The similarities of the trace metal signatures and the variety of fuels used in Mexico City did not allow us to identify a single, specific fuel type associated with these combustion sources.

The air mass back trajectories and OM concentrations provide some information about the differences among the combustion type factors. PSCF showed high OM concentrations of two of the combustion factors originated from similar source regions, and both of these factors correlated with dust markers (Al, Si, $\mathrm{Ca}$, and $\mathrm{Ti}$ ) at the Altzomoni site in addition to the combustion markers noted above. These common features provided evidence that both of these factors came from very similar and collocated sources. For these reasons, these two factors were combined to represent a "northeast combustion" factor, since they were associated most strongly with northeastern sources, likely from the industrial areas located at the northeastern MCMA (Fig. 5b, e; Johnson et al., 2006; Moffet et al., 2008b). The combined factor had stronger correlation with $\mathrm{S}$ than the individual uncombined factors. 
(a)

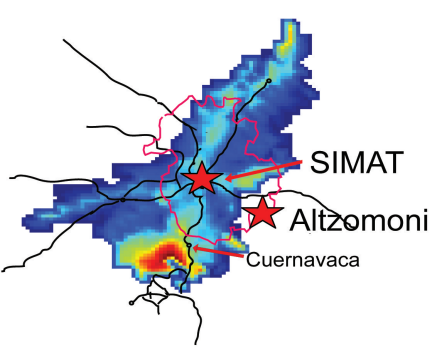

(d)

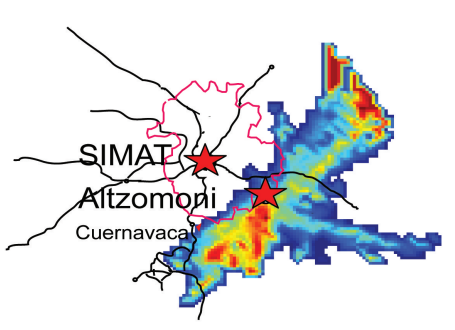

(b)

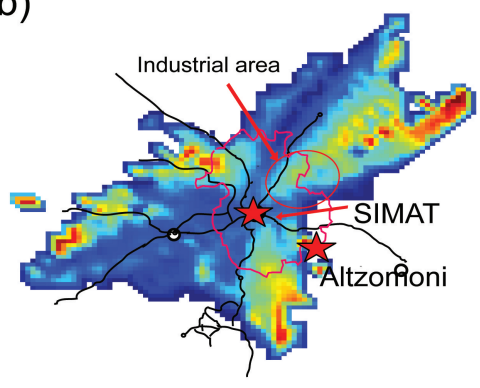

(e)

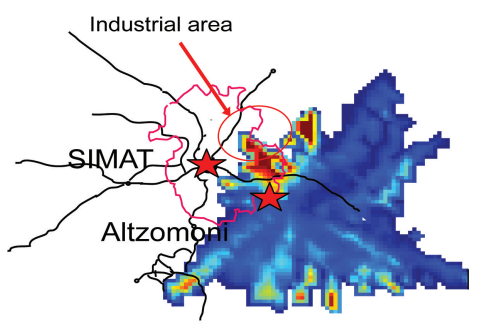

(c)

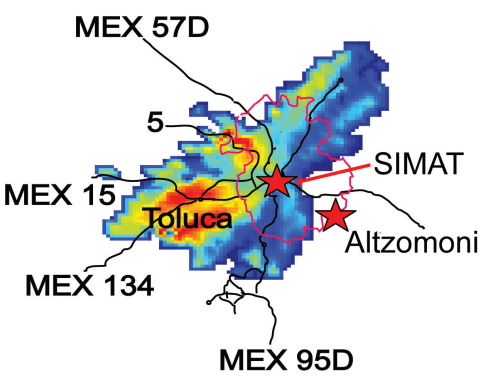

(f)

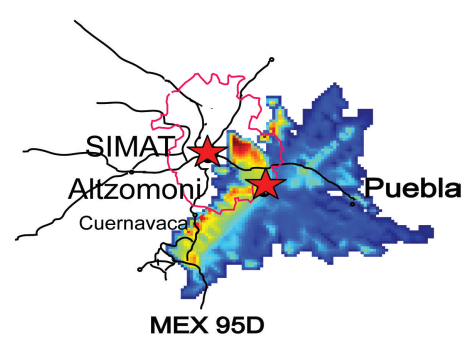

Fig. 5. PSCF of biomass burning, northeast combustion, and southwest combustion factors at SIMAT (a), (b), and (c) and at Altzomoni (d), (e), and (f). The color shows the probability of possible source regions of each factor with colder colors indicate lower possibilities.

Alkane functional group dominated this factor, accounting for $30-40 \%$ of the OM. At SIMAT, alcohol and carboxylic acid group fractions of this factor were comparable, accounting for $19 \%$ and $21 \%$ of the OM, respectively. At Altzomoni, alcohol group was a larger contributor to OM (37\%) than carboxylic group (19\%). This factor had the largest OM among all factors.

The factor associated with a strong source region located to the southwest of SIMAT (Fig. $5 \mathrm{c}$ ) close to the city of Toluca was denoted as the southwest combustion factor. Toluca is the capital city of Mexico State. Toluca has reduced air quality due to recent, rapid industrial growth (Aldape et al., 2008). The source region also tracked the freeways connecting Toluca and Mexico City, including freeways MEX 15 and MEX 134. Freeway 5 was also identified as a potential source. PSCF at Altzomoni showed the source region was near freeway MEX 95D (Fig. 5f). This factor represented industrial and motor vehicular emissions. Similar to the "northeast combustion" factor, alkane group dominated this factor but had a larger fraction of 44-51\%. Carboxylic acid group was the second largest component in this factor, accounting for $29-34 \%$ of the OM.

\subsection{PMF and clusters of STXM-NEXAFS spectra}

Three factors were consistently observed in $80 \%$ of all PMF runs. These factors were interpreted by comparing them with reference STXM-NEXAFS spectra of pure compounds and typical types of STXM-NEXAFS spectra identified in atmospheric particle measurements described by Takahama et al. (2007).

The first factor spectrum showed ketone and alkene group absorption peaks at $285 \mathrm{eV}$ and $287.7 \mathrm{eV}$. This factor was identified as a soot factor, as the shape of this factor spectrum was comparable to the soot type spectra (Fig. 6a) described by Braun et al. (2005) and Hopkins et al. (2007). The second factor spectrum was dominated by a strong carboxylic acid absorption peak at $288.7 \mathrm{eV}$ and shared similarities with the spectra of category (a) described by Takahama et al. (2007; Fig. 6b). Particles in category (a) are likely from secondary organic aerosol formation, so this factor was identified as a secondary factor. Factor 3 compared well with the STXM-NEXAFS spectrum for fulvic acid (Fig. 6c; Ade et al., 2002). Fulvic acid in atmospheric particles are likely to originate from biomass burning events (Tivanski et al., 2007), thus this factor was identified as a biomass burning factor. The 4-factor solution with a rotation of 0 resulted 
in the most representative results. This solution contained the three main factors identified above and an additional factor, which was present in only a few particles. The three main factors accounted for $80 \%$ of the particles analyzed by STXM-NEXAFS for the SIMAT and C130 during MILAGRO.

STXM-NEXAFS spectra were grouped into "secondary" type, "biomass burning" type, and "soot" type spectra described by Takahama et al. (2007). Figure 7 summarizes the size distributions of analyzed particles and the average fractions of the three major factors within each size range. The "secondary" type particles were in the size range of 0.2$5 \mu \mathrm{m}$, while the "biomass burning" and "soot" type particles were in the size range of $0.1-10 \mu \mathrm{m}$. The "soot" type particles were the most abundant, and $70 \%$ of these particles have diameters falling between 0.2 and $1 \mu \mathrm{m}$. The soot factor was the largest factor for particles smaller than $1 \mu \mathrm{m}$, and its fractions were lower in large size ranges. The biomass burning factor showed an increased fraction from submicron to supermicron size ranges.

\section{Discussion}

In this section, we consider how the organic mass and oxygenated fraction of organic mass are affected by diurnal trends at three platforms. We also use the FTIR spectral clusters to highlight the differences observed among the three platforms. Our PMF analysis provides a way to link some of these differences in measurements from the three platforms to the types of sources that affect each. In addition, we compare and contrast our results from STXM-NEXAFS spectra from single particle measurements and FTIR spectra from submicron bulk particle samples.

\subsection{Diurnal trend of functional groups and elements}

Samples were divided into "morning", "afternoon", and "night" categories according to the sampling time to investigate the differences of organic functional groups and elements as a function of time of day. Tukey's Honest Significant Difference method was applied to calculate the differences of the mean concentrations among the categories at a $90 \%$ confidence level.

At SIMAT, concentrations of OM, alkane, and carboxylic acid functional groups were found to be significantly higher in the morning than in the afternoon or at night. The high $\mathrm{OM}$ and organic functional group concentrations could be explained by either the emission of compounds containing alkane and carboxylic acid functional groups by traffic in the morning or by the low boundary layer in the early morning (Shaw et al., 2007). OM/OC and O/C was significantly higher in the afternoon, indicating that photochemical processes may contribute to the oxidation of organic compounds in the afternoon. Fractions of alcohol and carboxylic acid functional groups had higher values at night than in the afternoon, likely indicating the relative reduction of alkane functional groups and the concomitant accumulation of oxygenated compounds emitted and produced during the day.

At Altzomoni, concentrations of alkane groups, carboxylic acid groups, amine groups, Se, V, K, and S were found to be higher during the day than at night. Back trajectories at Altzomoni showed that the air masses mainly came from the east and southeast during daytime. The city of Puebla, which is located approximately $50 \mathrm{~km}$ east of Altzomoni, is the fourth most populous city in the country and has intense vehicular traffic as well as an important industrial zone in its metropolitan area (Juarez et al., 2005). The boundary layer can reach as high as $6 \mathrm{~km}$ during the day (Shaw et al., 2007), which is higher than the $4010 \mathrm{~m}$ location of the Altzomoni site. The elevated concentrations of those species during the day may be caused by the transport of pollutants from Puebla. During the night, the boundary layer decreased, and the site was influenced by air masses in the free troposphere, resulting in low concentrations.

No significant differences were found between the morning and afternoon for the C130 measurements, which is not surprising as the measurements were sparse and the sampling location for each observation varied on this mobile platform. While other studies have found that there were coarse particle concentration differences between weekdays and weekends (Stephens et al., 2008), differences in submicron organic functional group and elemental concentrations between days of the week were not found in this study for any platform.

\subsection{FTIR spectral clusters and $\mathrm{O} / \mathrm{C}$}

The shapes of spectra in cluster II are comparable to the spectral shapes in cluster $\mathrm{S} 1$ identified in shipboard measurements during TexAQS/GoMACCS 2006 near Houston (Russell et al., 2009). Sample spectra in cluster S1 were mainly from the relatively clean southerly flow from the Gulf or polluted by some nearby land-based sources. The similarities of the spectra from different geographical locations indicate that there are some common sources or processes occurring in the atmosphere.

Cluster I and cluster III mainly consist of spectra from SIMAT and Altzomoni, reflecting the similarities of submicron organic composition at these two platforms during certain time periods. Back trajectories at Altzomoni showed that air masses mainly came from northeast, east, and southeast of the site for samples in cluster I and cluster III, indicating the influence of urban pollution from Puebla, including vehicular and industrial emissions (Juarez et al., 2005). It is possible that the transport of Puebla plumes to Altzomoni resulted in organic particles with similar composition at Altzomoni and SIMAT.

Alkane, carboxylic acid, and alcohol groups were the main functional groups in particles and they accounted for more 


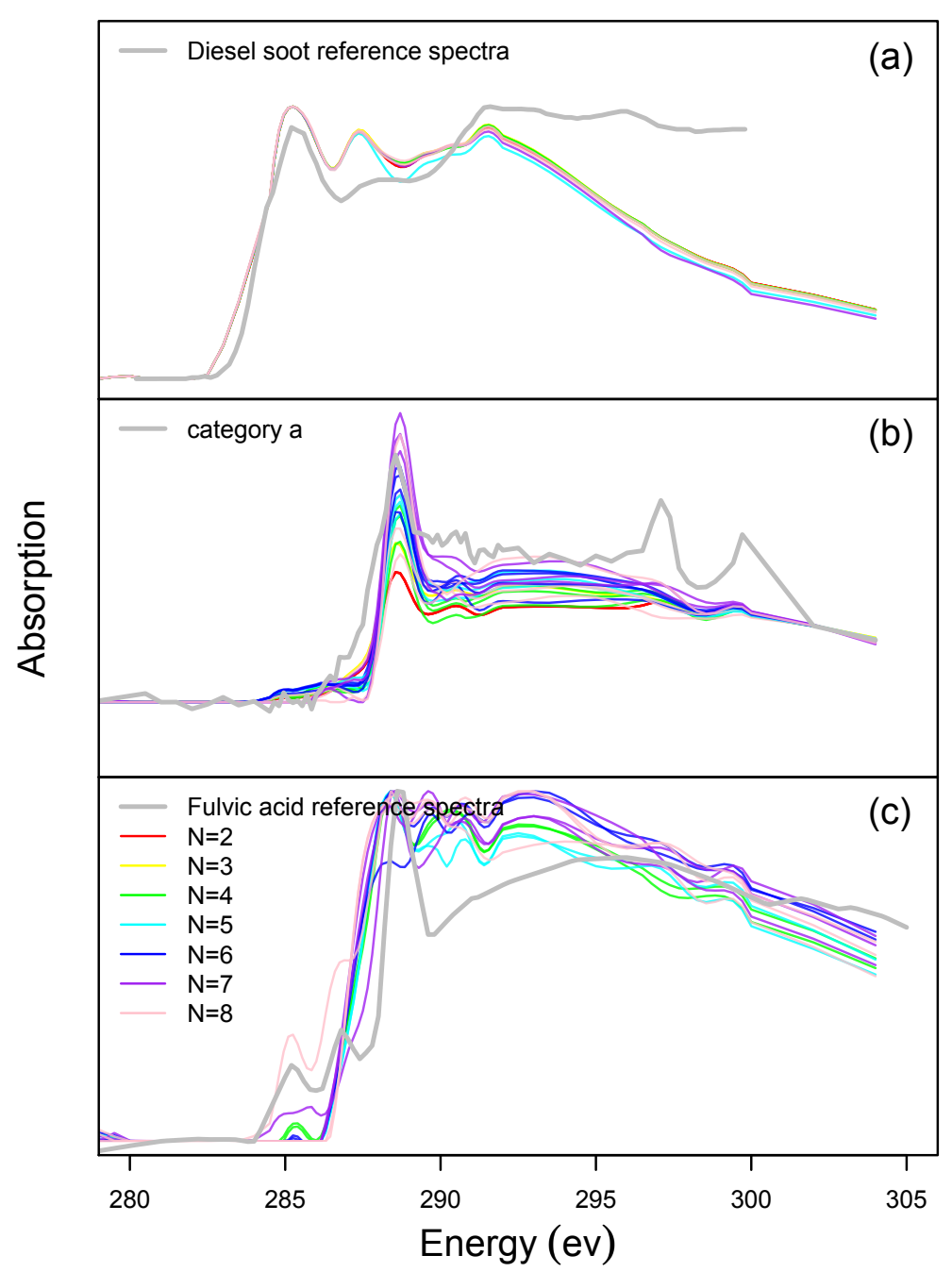

Fig. 6. Comparisons of major factor spectra from PMF of STXM-NEXAFS spectra with reference spectra: diesel soot (Braun, 2005), category a (Takahama et al., 2007), and fulvic acid (Ade and Urquhart, 2002). Colors indicate 2 (red), 3 (yellow), 4 (green), 5 (cyan), 6 (blue), 7 (purple), and 8-factor (pink) PMF run.

than $80 \%$ of OM for three platforms. Figure 9 shows the distributions of clustered spectra as a function of alkane, carboxylic acid, and alcohol group mass fractions. At SIMAT, the clustered spectra were relatively centered on the triangle plot, showing comparable mass fractions of the three main functional groups. At Altzomoni, cluster IV was separated from other clusters. Samples from cluster IV showed high alcohol group concentrations, and the highest $\mathrm{O} / \mathrm{C}$. This cluster mainly consisted of Altzomoni samples (Fig. 2), which were collected during times when the wind direction was from the north or northwest (Gilardoni et al., 2009), suggesting that cluster IV spectra may be associated with processed particles that originated in Mexico City.

\subsection{PMF factors and associated sources}

PMF factors attributed alkane, carboxylic acid, amine, and alcohol groups largely to combustion type sources. Industrial combustion and motor vehicular emissions are the most possible combustion sources in the MCMA (Stone et al., 2008; Johnson et al., 2006). This result supports the findings that direct emission processes, such as gasoline combustion and oil burning are sources of alkane and carboxylic acid groups in atmospheric particles (Rogge et al., 1993; Oros et al., 2000). Amines have also been suggested to originate from motor vehicle exhaust and industrial processes (Murphy et al., 2007). PMF attributed the main source of amine to combustion sources, which is consistent with the possible industrial sources discussed by Moffet et al. (2008b). Volatile organic compounds emitted from motor vehicles can form alcohol groups during photochemical processes (Sax et al., 


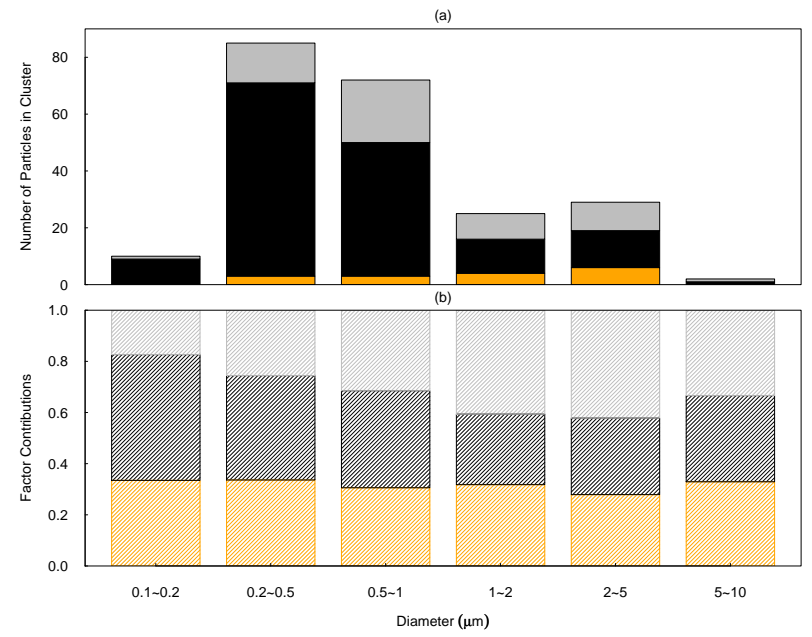

Fig. 7. (a) Size distributions of single particles for processed type (corresponding to category a), soot type (corresponding to categories $\mathrm{b}, \mathrm{c}, \mathrm{d}, \mathrm{e}, \mathrm{g}, \mathrm{h}$, and $\mathrm{m}$ ), and biomass burning type (corresponding to categories $i$ and $j$ ) particles described by Takahama et al. (2007) from cluster analysis of STXM-NEXAFS spectra. Colors indicate STXM-NEXAFS cluster categories for "processed" (orange), "soot" (black), and "biomass burning" (grey). (b) Average fractions of processed (orange), soot (black), and biomass burning (grey) factors in $0.1-0.2 \mu \mathrm{m}, 0.2-0.5 \mu \mathrm{m}, 0.5-1 \mu \mathrm{m}, 1-2 \mu \mathrm{m}, 2-$ $5 \mu \mathrm{m}$, and 5-10 $\mu \mathrm{m}$ size ranges for 4-factor PMF run of STXMNEXAFS spectra.

2005). Alcohol species are efficient additives added to lubricant oil to reduce friction (Lenard et al., 1998), thus the alcohol group could be from evaporation of oils used in gasoline and diesel motor vehicles. Sugar industries (Chollett, 2009) in the MCMA could be another source of the observed alcohol functional group. Biomass burning was the major source of the the non-acid carbonyl group, which could be from ketone- and aldehyde- containing species emitted as breakdown products during lignin burning processes (Oros et al., 1999; Simoneit et al., 1999).

Combustion was the major source of both $\mathrm{OM}$ and O/C. The $\mathrm{OM}$ and $\mathrm{O} / \mathrm{C}$ were dominated by the northeast combustion factor at the ground sites and by the southwest combustion factor during the flight measurement (Fig. 4). Biomass burning accounted for $0-8 \%$ of submicron organic mass (Fig. 4), which was close to the biomass burning contribution of $5-15 \%$ to $\mathrm{PM}_{2.5}$ at the T0 site suggested by Querol et al. (2008). We did not distinguish source types by direct emission and atmospherically-processed as all three combustion sources had weak correlations to combustion marker elements. The southwest combustion factor had the greatest fraction of carboxylic acid group among all factors and had relatively weaker correlations to elements compared to the northeast combustion factor. This factor probably had a larger atmospherically-processed component, which could be affected by meteorology or transport that weakened the correlation to tracers of a single source (Russell et al., 2009).

\subsection{Comparison of STXM-NEXAFS and FTIR factors from PMF}

While the single-particle STXM-NEXAFS spectra were sparse in terms of particle number and sampling times, the submicron particle types that were frequently identified were expected to have some organic components that were similar to the composition of submicron particle mass collected on bulk filters.

PMF of both single and bulk particle spectra resulted in biomass burning and combustion type factors. Figure $8 \mathrm{~b}$ shows the fractions of the northeast combustion factor, the southwest combustion factor, and the biomass burning factor of FTIR samples from SIMAT and C130 platforms. Clusters V, VI, and VII (exclusively consisted of C130 samples) were separated from the other clusters. Clusters II and III were separated: cluster II was associated with larger southwest combustion factor fractions, while cluster III was associated with greater northeast combustion factor fractions. Results from single particle spectra showed that the soot type particles were separated from biomass burning type particles (Fig. 8a). This indicates some clusters of both single particle spectra and bulk particle spectra were source-related.

Figure $8 \mathrm{a}$ shows that the contributions of soot and biomass burning factors to each ambient particle spectrum varied, but most particles showed consistent contributions from processing. The secondary factor accounted for $10-60 \%$ of the carbon absorbance, while the fractions of the other two factors showed a larger variation ranging from about $0-80 \%$ and 0 $90 \%$, suggesting the biomass burning and soot factors were more source-related, while the secondary factor had a consistent contribution to most particles. Figure $8 \mathrm{~b}$ shows that $85 \%$ of the samples had southwest factor fraction of OM between 30 and $65 \%$, while the northeast factor fraction of OM varied from 20 to $70 \%$. Both results show that the factors associated with processed component was more consistent during the sampling period than the combustion factors, since they had a smaller range of contribution for most particles.

\section{Conclusions}

Organic mass concentrations were $9.9 \mu \mathrm{g} \mathrm{m}^{-3}, 6.6 \mu \mathrm{g} \mathrm{m}^{-3}$, and $5.3 \mu \mathrm{g} \mathrm{m}^{-3}$ for SIMAT, Altzomoni, and C130 flight measurements. Alkane functional group concentrations dominated the OM, with the fractions ranging from $41 \%$ to $73 \%$. Dust markers $(\mathrm{Ca}, \mathrm{Fe}$, and $\mathrm{Si})$ correlated with each other for all three platforms, while combustion type elements showed different correlations among the three platforms. At SIMAT, two source-related groups of elements were identified: coal combustion type elements ( $\mathrm{S}$ and $\mathrm{Se}$ ) and $\mathrm{V}$ and $\mathrm{Ni}$ from oil combustions; while at Altzomoni, elements from several types of fossil fuel combustion $(\mathrm{V}, \mathrm{S}, \mathrm{K}, \mathrm{Br}, \mathrm{Pb}, \mathrm{Se})$ correlated with each other. For the $\mathrm{C} 130$ measurements, $\mathrm{Ca}$ was found to correlate with $\mathrm{S}, \mathrm{K}$, and $\mathrm{V}$. The differences in 
(a)

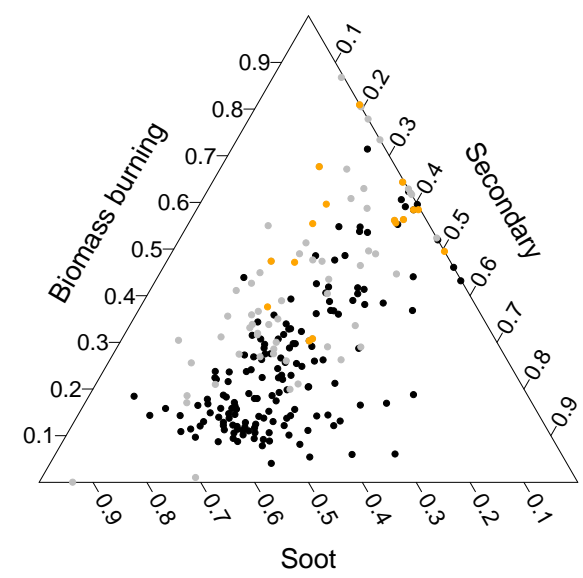

(b)

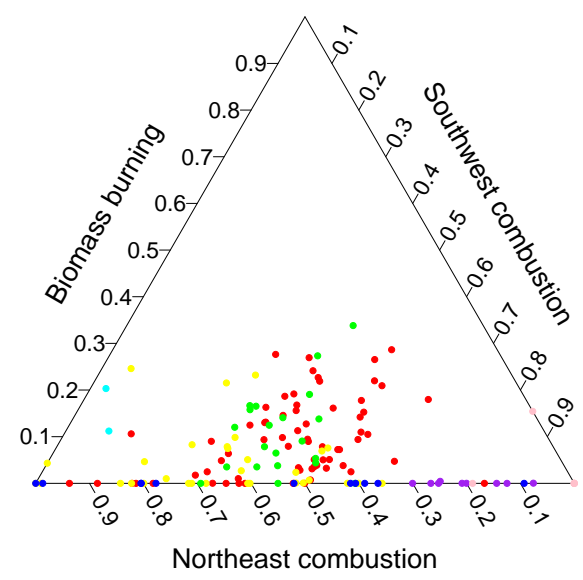

Fig. 8. (a): Ternary plot of soot, processed, and biomass burning factor fractions from PMF of STXM-NEXAFS spectra. Colors indicate clusters associated with soot type (b-e, g, h, m) particles (black), processed type (a) particles (orange), and biomass burning type (i, j) particles (grey). (b): Ternary plot of northeast combustion, biomass burning, and southwest combustion factor fractions resulted from PMF of FTIR spectra. Colors indicate cluster I (red), cluster II (yellow), cluster III (green), cluster IV (cyan), cluster V (blue), cluster VI (purple), and cluster VII (pink).

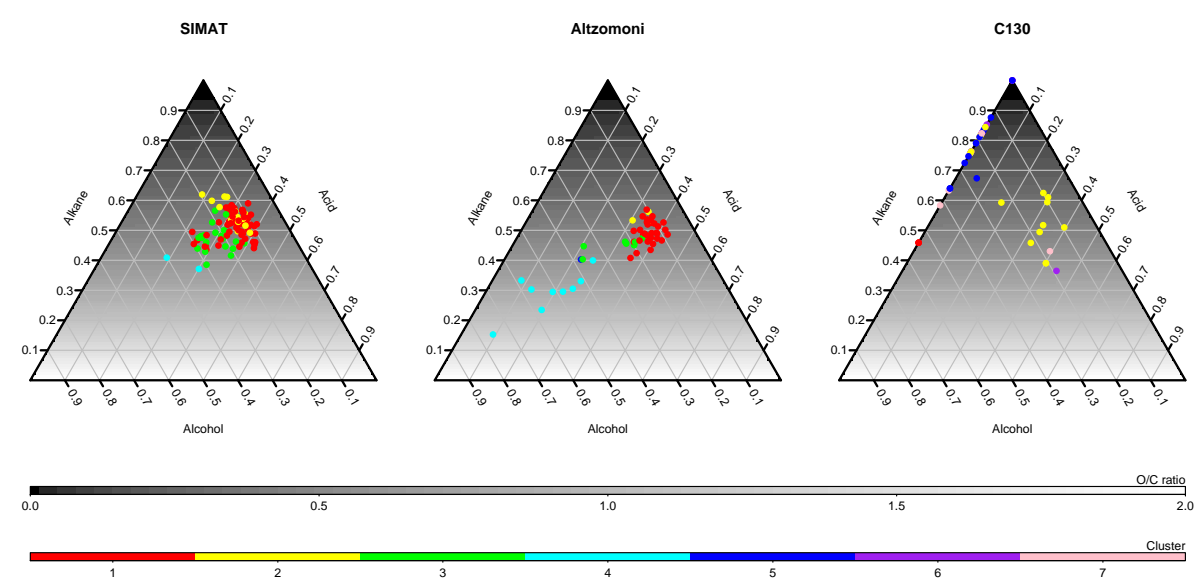

Fig. 9. Ternary plot of alcohol, alkane, and carboxylic acid functional group mass fractions of SIMAT, Altzomoni, and C130 FTIR measurements. Surface shading indicates O/C. Colors of cluster groups for FTIR spectra indicate cluster I (red), cluster II (yellow), cluster III (green), cluster IV (cyan), cluster V (blue), cluster VI (purple), and cluster VII (pink).

correlations of elements among the three platforms suggest that the urban area was more influenced by fresh emissions, while the high altitude site was more influenced by mixed sources or atmospheric (photochemical) processing.

The cluster analysis of FTIR spectra showed both similarities and differences among the three platforms. Seven distinct clusters of FTIR spectra were identified, from which the last three clusters consisted almost exclusively of samples collected aboard the $\mathrm{C} 130$ research flights based in Veracruz, indicating the wide variety of different sources and air masses sampled by the C130. More than $80 \%$ of SIMAT spectra and more than $70 \%$ of Altzomoni spectra are identified as clusters I and III, while cluster IV consists almost ex- clusively of Altzomoni spectra with high alcohol group fractions. The easterly and southeasterly transport of Puebla pollutants to Altzomoni may result in the similarities of organic particles from Altzomoni and SIMAT, while the distinct cluster IV of Altzomoni samples with high O/C suggests more processed particles at the Altzomoni site than at the SIMAT site.

PMF analysis was applied to STXM-NEXAFS spectra and FTIR spectra. PMF of STXM-NEXAFS spectra resulted in three main factors, which represented biomass burning, secondary, and fossil fuel combustion type spectra. PMF of FTIR spectra resulted in one biomass burning factor and two combustion factors, which were not attributed to specific 
source types as a consequence of the complexity of emission sources in the MCMA. The two combustion type factors were separated by potential source regions: one of them (the northeast combustion factor) was strongly associated with industrial sources to the northeast of SIMAT in the MCMA, and the other (the southwest combustion factor) could represent industrial and motor vehicular emissions mainly from the vicinity of City of Toluca. The southwest combustion factor has significant OM contributions from processed components, but a separate "processed" component was not identified. Several trends in composition were consistent for the factors and rotations selected. Combustion was the largest source of both $\mathrm{OM}$ and $\mathrm{O} / \mathrm{C}$. PMF attributed alkane, carboxylic acid, amine, and alcohol functional groups largely to combustion sources, among which industrial and motor vehicular emissions were the most probable contributors. Biomass burning contributed to a small fraction (0-8\%) of submicron particle mass. Non-acid carbonyl groups, which could be emitted as breakdown products during lignin or other biomass burning (Simoneit et al., 1999), dominated this factor. Both PMF of single particle STXM-NEXAFS spectra and PMF of submicron FTIR spectra showed that the clusters were associated with different fractions of the factor contributions. Narrower ranges of the fraction of the processed factor contributions to single particles and submicron OM (10 to $60 \%$ from PMF of single particle spectra and 35 to $60 \%$ from PMF of submicron OM spectra) than combustion type factors suggests that the combustion factors (0-90\%) varied more with local sources, while the factors related to atmospheric processing were more constant during the campaign.

\section{Appendix A}

\section{FTIR calibrations of amine functional groups}

Calibrations of organic functional groups of FTIR spectra were conducted using the measured absorption per mole of each component from laboratory-generated standards (Maria et al., 2002). Three primary amine standards (nTridecylamine, n-Tetradecylamine, alanine ) and three secondary amine standards (N-Methyl-n-octadecylamine, Din-decylamine, Di-n-dodecylamine) were used to quantify amine functional group absorption at $1625 \mathrm{~cm}^{-1}$ observed in our ambient particle spectra. Results showed that secondary amines do not have detectable absorption peaks at $1625 \mathrm{~cm}^{-1}$. Alanine was used as the standard for quantification of primary amine groups as it best represents the absorption peak at $1625 \mathrm{~cm}^{-1}$. The revised guided algorithm (Russell et al., 2009) was applied to do peak fitting and integration of alanine standard spectra. The absorptivity of amine functional group is $0.12 \mu \mathrm{mol} / \mathrm{unit}$ of peak area, with a linear fit $\left(R^{2}=0.97\right)$ of absorption and moles per functional group. Deviations from this absorptivity were not observed for mixtures of alanine and ammonium sulfate. Possibili- ties of absorption at $1625 \mathrm{~cm}^{-1}$ by organonitrate compounds were ruled out by the absence of absorption at $1280 \mathrm{~cm}^{-1}$ in the ambient FTIR spectra (Mylonas et al., 1991; Allen et al., 1994; Garnes et al., 2002; Laurent et al., 2004). Water absorption at $1625 \mathrm{~cm}^{-1}$ is removed by purging the sample chamber of FTIR instrument for 3 min before scanning each sample.

Acknowledgements. The authors appreciate the funding from DOE (Department Of Energy W/GEC05-010 and MPC35TA-A5) and NSF (National Science Foundation ATM-0511772).

Edited by: S. Madronich

\section{References}

Ade, H. and Urquhart, S. G.: NEXAFS spectroscopy and microscopy of natural and synthetic polymers, in: Chemical Applications of Synchrotron Radiation, World Scientific Publishing, Singapore, 285-355, 2002.

Aldape, F., Flores, J. M. and Martínez-pontón, A. A.: Evaluation of fine airborne particulate matter at toluca, Estado de Mexico, using pixe, International Journal of PIXE, 18 (Nos. 3 and 4), 187197, 2008.

Aiken, A. C., Decarlo, P. F., Kroll, J. H., Worsnop, D. R., Huffman, J. A., Docherty, K. S., Ulbrich, I. M., Mohr, C., Kimmel, J. R., Sueper, D., Sun, Y., Zhang, Q., Trimborn, A., Northway, M., Ziemann, P. J., Canagaratna, M. R., Onasch, T. B., Alfarra, M. R., Prevot, A. S. H., Dommen, J., Duplissy, J., Metzger, A., Baltensperger, U., and Jimenez, J. L.: O/C and OM/OC ratios of primary, secondary, and ambient organic aerosols with high-resolution time-of-flight aerosol mass spectrometry, Environ. Sci. Technol., 42(12), 4478-4485, 2008.

Aiken, A. C., de Foy, B., Wiedinmyer, C., et al.: Mexico City aerosol analysis during MILAGRO using high resolution aerosol mass spectrometry at the urban supersite (T0) - Part 2: Analysis of the biomass burning contribution and the modern carbon fraction, Atmos. Chem. Phys., in preparation, 2009.

Allen, D. T., Palen, E. J., Haimov, M. I., Hering, S. V., and Young, J. R.: Fourier-Transform Infrared-Spectroscopy Of Aerosol Collected In A Low-Pressure Impactor (Lpi/Ftir) - Method Development And Field Calibration, Aerosol Sci. Tech., 21(4), 325-342, 1994.

Balasubramanian, R. and Qian, W. B.: Characterization and source identification of airborne trace metals in Singapore, J. Environ. Monitor., 6(10), 813-818, 2004.

Baumgardner, D., Grutter, M., Allan, J., Ochoa, C., Rappenglueck, B., Russell, L. M., and Arnott, P.: Physical and chemical properties of the regional mixed layer of Mexico's Megapolis, Atmos. Chem. Phys., 9, 5711-5727, 2009, http://www.atmos-chem-phys.net/9/5711/2009/.

Braun, A., Shah, N., Huggins, F. E., Kelly, K. E., Sarofim, A., Jacobsen, C., Wirick, S., Francis, H., Ilavsky, J., Thomas, G. E., and Huffman, G. P.: X-ray scattering and spectroscopy studies on diesel soot from oxygenated fuel under various engine load conditions, Carbon, 43(12), 2588-2599, 2005.

Chollett, D. L.: From Sugar to Blackberries Restructuring Agroexport Production in Michoacan, Mexico, Latin American Perspectives, 36(3), 79-92, 2009. 
Chow, J. C., Watson, J. G., Edgerton, S. A., and Vega, E.: Chemical composition of $\mathrm{PM}_{2.5}$ and $\mathrm{PM}_{10}$ in Mexico City during winter 1997, Sci. Total Environ., 287(3), 177-201, 2002.

CICA: Emissions from Street Vendor Cooking Devices (Charcoal Grilling), EPA-600/R-99-048, available at: http://www.epa.gov/ ttn/catc/dir1/mexfr.pdf(last access: 29 January 2009), 1999.

DeCarlo, P. F., Dunlea, E. J., Kimmel, J. R., Aiken, A. C., Sueper, D., Crounse, J., Wennberg, P. O., Emmons, L., Shinozuka, Y., Clarke, A., Zhou, J., Tomlinson, J., Collins, D. R., Knapp, D., Weinheimer, A. J., Montzka, D. D., Campos, T., and Jimenez, J. L.: Fast airborne aerosol size and chemistry measurements above Mexico City and Central Mexico during the MILAGRO campaign, Atmos. Chem. Phys., 8, 4027-4048, 2008, http://www.atmos-chem-phys.net/8/4027/2008/.

Dockery, D. W., Pope, C. A., Xu, X. P., Spengler, J. D., Ware, J. H., Fay, M. E., Ferris, B. G., and Speizer, F. E.: An Association Between Air-Pollution And Mortality In 6 United-States Cities, New Engl. J. Med., 329(24), 1753-1759, 1993.

Eidels-Dubovoi, S.: Aerosol impacts on visible light extinction in the atmosphere of Mexico City, Sci. Total Environ., 287(3), 213220, 2002.

Finlayson-Pitts, B. J. and Pitts, J. N.: Chemistry of the Upper and Lower Atmosphere, Academic Press, San Diego, USA, 386-388, 2000.

Escudero, M., Stein, A., Draxler, R. R., Querol, X., Alastuey, A., Castillo, S. and Avila, A.: Determination of the contribution of northern Africa dust source areas to PM10 concentrations over the central Iberian Peninsula using the Hybrid Single-Particle Lagrangian Integrated Trajectory model (HYSPLIT) model, J. Geophys. Res.-Atmos., 111(D6), D06210, doi:10.1029/2005JD006395, 2006.

Flores, J., Aldape, F., Diaz, R. V., Hernandez-Mendez, B., and Garcia, R.: PIXE analysis of airborne particulate matter from Xalostoc, Mexico: winter to summer comparison, Nuclear Instruments and Methods In Physics Research Section B-Beam Interactions With Materials And Atoms, 150(1-4), 445-449, 1999.

Garnes, L. A. and Allen, D. T.: Size distributions of organonitrates in ambient aerosol collected in Houston, Texas, Aerosol Sci. Technol., 36(10), 983-992, 2002.

Gilardoni, S., Russell, L. M., Sorooshian, A., Flagan, R. C., Seinfeld, J. H., Bates, T. S., Quinn, P. K., Allan, J. D., Williams, B., Goldstein, A. H., Onasch, T. B., and Worsnop, D. R.: Regional variation of organic functional groups in aerosol particles on four US east coast platforms during the International Consortium for Atmospheric Research on Transport and Transformation 2004 campaign, J. Geophys. Res.-Atmos., 112, D10S27, doi:10.1029/2006JD007737, 2007.

Gilardoni, S., Liu, S., Takahama, S., Russell, L. M., Allan, J. D., Steinbrecher, R., Jimenez, J. L., Decarlo, P. F., Dunlea, E. J. and Baumgardner, D.: Characterization of organic ambient aerosol during MIRAGE 2006 on three platforms, Atmos. Chem. Phys., 9, 5417-5432, 2009,

http://www.atmos-chem-phys.net/9/5417/2009/.

Hopkins, R. J., Tivanski, A. V., Marten, B. D., and Gilles, M. K.: Chemical bonding and structure of black carbon reference materials and individual carbonaceous atmospheric aerosols, J, Aerosol Sci,, 38(6), 573-591, 2007.

Johnson, K. S., de Foy, B., Zuberi, B., Molina, L. T., Molina, M. J., Xie, Y., Laskin, A., and Shutthanandan, V.: Aerosol composi- tion and source apportionment in the Mexico City Metropolitan Area with PIXE/PESA/STIM and multivariate analysis, Atmos. Chem. Phys., 6, 4591-4600, 2006,

http://www.atmos-chem-phys.net/6/4591/2006/.

Juarez, A., Gay, C., and Flores, Y.: Impact of the Popocatepetl's volcanic activity on the air quality of Puebla City, Mexico, Atmosfera, 18(1), 57-69, 2005.

Kaufman, L. and Rousseeuw, P. J.: Finding Groups in Data: An Introduction to cluster Analysis, Wiley, New York, USA, 45-48, 1990.

Keller, H. R., Massart, D. L., Liang, Y. Z., and Kvalheim, O. M.: Evolving Factor-Analysis In The Presence Of Heteroscedastic Noise, Analytica Chimica Acta, 263(1-2), 29-36, 1992.

Laurent, J. P. and Allen, D. T.: Size distributions of organic functional groups in ambient aerosol collected in Houston, Texas, Aerosol Sci. Technol., 38, 82-91, 2004.

Lee, E., Chan, C. K., and Paatero, P.: Application of positive matrix factorization in source apportionment of particulate pollutants in Hong Kong, Atmos. Environ., 33(19), 3201-3212, 1999.

Lenard, J. G.: The effect of lubricant additives on the coefficient of friction in cold rolling, J. Mat. Proc. Technol., 80(1), 232-238, 1998.

Li, Z., Hopke, P. K., Husain, L., Qureshi, S., Dutkiewicz, V. A., Schwab, J. J., Drewnick, F., and Demerjian, K. L.: Sources of fine particle composition in New York city, Atmos. Environ., 38(38), 6521-6529, 2004.

Liepert, B. G., Feichter, J., Lohmann, U., and Roeckner, E.: Can aerosols spin down the water cycle in a warmer and moister world?, Geophys. Res. Lett., 31, L06207, doi:10.1029/2003GL019060, 2004.

Maria, S. F., Russell, L. M., Turpin, B. J., and Porcja, R. J.: FTIR measurements of functional groups and organic mass in aerosol samples over the Caribbean, Atmos. Environ., 36(33), 51855196, 2002.

Maria, S. F., Russell, L. M., Turpin, B. J., Porcja, R. J., Campos, T. L., Weber, R. J., and Huebert, B. J.: Source signatures of carbon monoxide and organic functional groups in Asian Pacific Regional Aerosol Characterization Experiment (ACE-Asia) submicron aerosol types, J. Geophys. Res.-Atmos., 108(D23), 8637, doi:10.1029/2003JD003703, 2003.

Maria, S. F., Russell, L. M., Gilles, M. K., and Myneni, S. C. B.: Organic aerosol growth mechanisms and their climate-forcing implications, Science, 306(5703), 1921-1924, 2004.

Maria, S. F. and Russell, L. M.: Organic and inorganic aerosol below-cloud scavenging by suburban New Jersey precipitation, Environ. Sci. Technol., 39, 13, 4793-4800, 2005.

Moffet, R. C., Desyaterik, Y., Hopkins, R. J., Tivanski, A. V., Gilles, M. K., Wang, Y., Shutthanandan, V., Molina, L. T., Abraham, R. G., Johnson, K. S., Mugica, V., Molina, M. J., Laskin, A., and Prather, K. A.: Characterization of aerosols containing $\mathrm{Zn}, \mathrm{Pb}$, and $\mathrm{Cl}$ from an industrial region of Mexico City, Environ. Sci. Technol., 42(19), 7091-7097, 2008a.

Moffet, R. C., de Foy, B., Molina, L. T., Molina, M. J., and Prather, K. A.: Measurement of ambient aerosols in northern Mexico City by single particle mass spectrometry, Atmos. Chem. Phys., 8, 4499-4516, 2008b, http://www.atmos-chem-phys.net/8/4499/2008/.

Molina, L. T., Kolb, C. E., de Foy, B., Lamb, B. K., Brune, W. H., Jimenez, J. L., Ramos-Villegas, R., Sarmiento, J., Paramo- 
Figueroa, V. H., Cardenas, B., Gutierrez-Avedoy, V., and Molina, M. J.: Air quality in North America's most populous city overview of the MCMA-2003 campaign, Atmos. Chem. Phys., 7, 2447-2473, 2007,

http://www.atmos-chem-phys.net/7/2447/2007/.

Murphy, S. M., Sorooshian, A., Kroll, J. H., Ng, N. L., Chhabra, P., Tong, C., Surratt, J. D., Knipping, E., Flagan, R. C., and Seinfeld, J. H.: Secondary aerosol formation from atmospheric reactions of aliphatic amines, Atmos. Chem. Phys., 7, 2313-2337, 2007, http://www.atmos-chem-phys.net/7/2313/2007/.

Mylonas, D. T., Allen, D. T., Ehrman, S. H., and Pratsinis, S. E.: The Sources And Size Distributions Of Organonitrates In LosAngeles Aerosol, Atmos. Environ. A-Gen., 25, 12, 2855-2861, 1991.

Oros, D. R. and Simoneit, B. R. T.: Identification of molecular tracers in organic aerosols from temperate climate vegetation subjected to biomass burning, Aerosol Sci. Technol., 31(6), 433445, 1999.

Oros, D. R. and Simoneit, B. R. T.: Identification and emission rates of molecular tracers in coal smoke particulate matter, Fuel, 79(5), 515-536, 2000.

Paatero, P. and Tapper, U.: Positive Matrix Factorization - A Nonnegative Factor Model With Optimal Utilization Of ErrorEstimates Of Data Values, Environmetrics, 5(2), 111-126, 1994.

Pekney, N. J., Davidson, C. I., Zhou, L. M., and Hopke, P. K.: Application of PSCF and CPF to PMF-modeled sources of $\mathrm{PM}_{2.5}$ in Pittsburgh, Aerosol Sci. Technol., 40(10), 952-961, 2006.

Querol, X., Pey, J., Minguillón, M. C., Pérez, N., Alastuey, A., Viana, M., Moreno, T., Bernabé, R. M., Blanco, S., Cárdenas, B., Vega, E., Sosa, G., Escalona, S., Ruiz, H., and Artíñano, B.: PM speciation and sources in Mexico during the MILAGRO-2006 Campaign, Atmos. Chem. Phys., 8, 111-128, 2008, http://www.atmos-chem-phys.net/8/111/2008/.

Qureshi, S., Dutkiewicz, V. A., Khan, A. R., Swami, K., Yang, K. X., Husain, L., Schwab, J. J., and Demerjian, K. L.: Elemental composition of $\mathrm{PM}_{2.5}$ aerosols in Queens, New York: Solubility and temporal trends, Atmos. Environ., 40, S238-S251, 2006.

Raga, G. B., Baumgardner, D., Castro, T., Martinez-Arroyo, A., and Navarro-Gonzalez, R.: Mexico City air quality: a qualitative review of gas and aerosol measurements (1960-2000), Atmos. Environ., 35(23), 4041-4058, 2001.

Ramadan, Z., Song, X. H., and Hopke, P. K.: Identification of sources of Phoenix aerosol by positive matrix factorization, J. Air Waste Manage., 50(8), 1308-1320, 2000.

Rogge, W. F., Hildemann, L. M., Mazurek, M. A., Cass, G. R., and Simoneit, B. R. T.: Sources Of Fine Organic Aerosol. 2. Noncatalyst And Catalyst-Equipped Automobiles And Heavy-Duty Diesel Trucks, Environ. Sci. Technol., 27(4), 636-651, 1993.

Russell, L. M., Maria, S. F., and Myneni, S. C. B.: Mapping organic coatings on atmospheric particles, Geophys. Res. Lett., 29(16), 1779, doi:10.1029/2002GL014874, 2002.

Russell, L. M., Takahama, S., Liu, S., Hawkins, L. N., Covert, D. S., Quinn, P. K., and Bates, T. S.: Oxygenated fraction and mass of organic aerosol from direct emission and atmospheric processing measured on the R/V Ronald Brown during TEXAQS/GoMACCS 2006, Journal Of Geophysical ResearchAtmospheres, 114, D00F05, doi:10.1029/2008JD011275, 2009.

Salcedo, D., Onasch, T. B., Dzepina, K., Canagaratna, M. R., Zhang, Q., Huffman, J. A., DeCarlo, P. F., Jayne, J. T., Mor- timer, P., Worsnop, D. R., Kolb, C. E., Johnson, K. S., Zuberi, B., Marr, L. C., Volkamer, R., Molina, L. T., Molina, M. J., Cardenas, B., Bernabé, R. M., Márquez, C., Gaffney, J. S., Marley, N. A., Laskin, A., Shutthanandan, V., Xie, Y., Brune, W., Lesher, R., Shirley, T., and Jimenez, J. L.: Characterization of ambient aerosols in Mexico City during the MCMA-2003 campaign with Aerosol Mass Spectrometry: results from the CENICA Supersite, Atmos. Chem. Phys., 6, 925-946, 2006,

http://www.atmos-chem-phys.net/6/925/2006/.

Sax, M., Zenobi, R., Baltensperger, U., and Kalberer, M.: Time resolved infrared spectroscopic analysis of aerosol formed by photo-oxidation of 1,3,5-trimethylbenzene and alpha-pinene, Aerosol Sci. Technol., 39(9), 822-830, 2005.

Shilling, J. E., Chen, Q., King, S. M., Rosenoern, T., Kroll, J. H., Worsnop, D. R., DeCarlo, P. F., Aiken, A. C., Sueper, D., Jimenez, J. L., and Martin, S. T.: Loading-dependent elemental composition of $\alpha$-pinene SOA particles, Atmos. Chem. Phys., 9, 771-782, 2009, http://www.atmos-chem-phys.net/9/771/2009/.

Sharma, M. and Maloo, S.: Assessment of ambient air $\mathrm{PM}_{10}$ and $\mathrm{PM}_{2.5}$ and characterization of $\mathrm{PM}_{10}$ in the city of Kanpur, India, Atmos. Environ., 39(33), 6015-6026, 2005.

Shaw, W. J., Pekour, M. S., Coulter, R. L., Martin, T. J., and Walters, J. T.: The daytime mixing layer observed by radiosonde, profiler, and lidar during MILAGRO, Atmos. Chem. Phys. Discuss., 7, 15025-15065, 2007, http://www.atmos-chem-phys-discuss.net/7/15025/2007/.

Simoneit, B. R. T., Schauer, J. J., Nolte, C. G., Oros, D. R., Elias, V. O., Fraser, M. P., Rogge, W. F., and Cass, G. R.: Levoglucosan, a tracer for cellulose in biomass burning and atmospheric particles, Atmos. Environ., 33 (2), 173-182, 1999.

Stephens, S., Madronich, S., Wu, F., Olson, J. B., Ramos, R., Retama, A., and Muñoz, R.: Weekly patterns of México City's surface concentrations of $\mathrm{CO}, \mathrm{NO}_{\mathrm{x}}, \mathrm{PM}_{1} \mathrm{O}$ and $\mathrm{O}_{3}$ during 19862007, Atmos. Chem. Phys., 8, 5313-5325, 2008, http://www.atmos-chem-phys.net/8/5313/2008/.

Stone, E. A., Snyder, D. C., Sheesley, R. J., Sullivan, A. P., Weber, R. J., and Schauer, J. J.: Source apportionment of fine organic aerosol in Mexico City during the MILAGRO experiment 2006, Atmos. Chem. Phys., 8, 1249-1259, 2008, http://www.atmos-chem-phys.net/8/1249/2008/.

Takahama, S., Gilardoni, S., Russell, L. M., and Kilcoyne, A. L. D.: Classification of multiple types of organic carbon composition in atmospheric particles by scanning transmission X-ray microscopy analysis, Atmos. Environ., 41(40), 9435-9451, 2007.

Tivanski, A. V., Hopkins, R. J., Tyliszczak, T., and Gilles, M. K.: Oxygenated interface on biomass burn tar balls determined by single particle scanning transmission X-ray microscopy, J. Phys. Chem. A, 111(25), 5448-5458, 2007.

Vega, E., Garcia, I., Apam, D., Ruiz, M. E., and Barbiaux, M.: Application of a chemical mass balance receptor model to respirable particulate matter in Mexico city, J. Air Waste Manage., 47(4), 524-529, 1997.

Ward, J. H.: Hierarchical Grouping To Optimize An Objective Function, J. Am. Stat. Assoc., 58(301), 236-244, 1963.

Yokelson, R. J. and Urbanski, S. P.: Emissions from forest fires near Mexico City, Atmos. Chem. Phys., 7, 5569-5584, 2007, http://www.atmos-chem-phys.net/7/5569/2007/. 